\title{
Influence of Artocarpus heterophyllus in benzopyrene induced lung cancer
}

\section{Thiruselvi, $\mathbf{M}^{1}$ and Brindha Durairaj ${ }^{2}$}

${ }^{1}$ Assistant Professor, Department of Biochemistry, Dr. N.G.P Arts and Science College, Coimbatore641048, Tamil Nadu; ${ }^{2}$ Professor \& Principal, PSG College of Arts and Science, Coimbatore-641014, Tamil Nadu;

Address for Correspondence

Dr.M.Thiruselvi, Assistant Professor, Dr.N.G.P Arts and Science College, Coimbatore-641048, Tamil Nadu.

Email: mthiruselvi@gmail.com 


\begin{abstract}
Lung cancer a deadliest cancer worldwide and the most common cancer in the whole of Asia. The present study focused on the protective efficacy of Artocarpus heterophyllus in benzopyrene induced lung toxicity in C57BL/6 Mice. Mice were orally induced with benzopyrene and treated with hydroethanolic extract of spermoderm of Artocarpus heterophyllus (HESA) at a dose of (50mg/kg.b.wt and 100mg/kg.b.wt). The oral administration of HESA effectively suppressed lung cancer as revealed by the decrease in the extent of haematological parameters with concomitant decrease in the activities of serum markers. Significantly protein expressions of p53 and $\mathrm{Bcl}_{2}$ in the lung tissue were further confirmed that coadministration of the extract treatment however downregulated their expressions by decreasing the marker of positively stained cells and restored the histopathological alteration of lung tissue. Our results suggest that HESA can be used as a protective agent against benzopyrene induced lung cancer.
\end{abstract}

Keywords: Artocarpus heterophyllus, Benzopyrene, Serum markers, Lung cancer 


\section{INTRODUCTION}

Cancer is deliberated to be the major health problem and one of the major leading causes of mortality in the world. Over all survival is challenging to forecast, due to the range of genetic defects leading to the development of cancer (Rajandeepkaur, 2011). Among all type of cancer, lung cancer is considered to be the most frequently occurring disease and the prevalence is high in men than women (Adebayor, 2010). The lung cancer is predominantly caused by smoking, nearly $90 \%$ of lung cancers are being reported due to smoking and studies show that smoking causes a high mortality rate(Vanitha et al., 2017). A further aspect is radon gas, certain chemicals inhaled and asbestos, have a high risk for lung cancer (Prakash et al., 2013). A long term exposure to polluted air can also cause cancer to the lungs(Greenwell and Rahman, 2015). National Institute of cancer states that in the course of lung cancer, non-small cell cancer found to be more instigated when compared to small cell lung cancer (Apte, 2016 and Rethy 2007). A comprehensive prognosis is necessary to provide a meticulous report about the existing condition of disease and considerably important before screening and diagnosis. This will state about the metastatic movement, cell types and any signs of initiation of lung cancer (Ngamkitidechakul et al., 2010 and Sudhakar, 2009).

Many pharmacological developments have been made in the staging and treatment of

lung cancer over decades, further research on medicinal plants is needed to ascertain early prevention of lung cancers. An abundant number of evidence suggests that increased consumption of fruits and vegetables is a relatively easy and practical strategy to reduce significantly the incidence of cancer (Obeidat and Sharab, 2018). Artocarpus heterophyllus belongs to the family Moraceae, It is also reported for a rich source of phytochemicals which embraces various enzyme that is been used in growth supplementation (Ali et al., 2017). The bioactive compound of Artocarpus heterophyllus is widely used in treating asthma, ulcer, 
ophthalmological disorders and combination of latex with vinegar helps in snakebite and swellings(Nath et al., 2017). Voluminous pharmacological studies are performed and reported for its anti-inflammatory, antidiabetic, and antibacterial activity (Tiwari, 2017 and Fuadhafid, 2017) Apart from this, the studies have revealed for leaves also exhibit antioxidant potential which can act against cancer. Earlier research conducted in our laboratory demonstrated that the seeds of Artocarpus heterophyllus are good source bioactive compounds and the influence of HESA on A549 cell line revealed the in vitro anticancer activity. The current research was designed to investigate the chemoprotective efficacy of HESA on benzopyrene induced lung cancer.

\section{Materials and Methods}

\section{Plant materials and extraction}

Artocarpus heterophyllus seeds were obtained from market, Trivandrum, Kerala. The inner thin membranous brown tegmen (Spermoderm) of Artocarpus heterophyllus seeds were used for the present study. The plant was identified and authenticated at Botanical Survey of India, Coimbatore (No: BSI/SRC/5/23/2018/Tech-383). About $25 \mathrm{~g}$ of the inner thin membranous spermoderm of the Jack fruit seeds were dried and powdered. The powdered material of Artocarpus heterophyllus seeds was extracted with hydroethanol using Soxhlet extractor exhaustively for 20-24 hours. The extracts were concentrated to dryness under reduced pressure and controlled temperature $\left(40-50^{\circ} \mathrm{C}\right)$. The dried extracts obtained were used in this study.

Benzopyrene (Sigma chemicals) was purchased St. Louis, USA. All other chemicals (analytical grade) were procured from SRL chemicals Pvt. Ltd., Mumbai, India. 


\section{Selection of Animals}

The C57BL/6 Male mice (8-10 weeks old, 20-25g) were obtained from Sri Venkateshwara Enterprises (Bangalore, India). All the experiments involving animals were carried out as per the guidelines from the Institutional Animal Ethics Committee (IAEC/KU/02/15). The mice were retained under conditions of controlled temperature $\left(26 \pm 2^{\circ}\right)$ with 12-hrs day/night cycle. The standard rat/mice pellet diet was followed to all the mice and were given access to water and libitum (Sai Durga Feeds, Bangalore, India).

\section{Experimental design}

Experimental animals were divided into four groups with six mice each as follows. Group I (control) - olive oil was given orally throughout the course of the experiment. Group II (benzopyrene induced) - received benzopyrene dissolved in olive oil (100 $\mathrm{mg} / \mathrm{kg}$ body weight) orally for 6 weeks (thrice a week). Group III and IV after induction of lung cancer, extracts with two different concentrations (50mg/kg.b.wt and $100 \mathrm{mg} / \mathrm{kg}$.b.wt) has been given for 4 weeks orally on alternative days. After the experimental period animals were sacrificed under ether anesthesia by cervical decapitation. Lungs were removed immediately and washed with ice-cold saline. To obtain an index of tumour incidence, the percentage of tumour-bearing mice per total number of mice in each group was calculated. A $10 \%$ homogenate of the washed tissue (lung) was prepared in $0.01 \mathrm{M}$ phosphate buffer ( $\mathrm{pH}$ 7.4). The homogenate was centrifuged at a speed of $12,000 \times \mathrm{g}$ for $30 \mathrm{~min}$ in a refrigerated high-speed centrifuge at $4^{\circ} \mathrm{C}$. Blood was also collected and the serum was separated for following the biochemical analysis.

\section{Collection of samples}

After the experimental period animals were sacrificed by cervical decapitation under ether anesthesia and lungs were excised immediately and washed with ice-cold saline. To obtain an 
index of tumor incidence, the percentage of tumor bearing mice per total number of mice in each group was calculated.

\section{Biochemical Analysis and Heamatological Parameters}

A $10 \%$ homogenate of the washed lung tissue was prepared in $0.01 \mathrm{M}$ phosphate buffer ( $\mathrm{pH}$ 7.4). The homogenate was centrifuged at a speed of $12,000 \times \mathrm{g}$ for $30 \mathrm{~min}$ in a refrigerated high-speed centrifuge at $4^{\circ} \mathrm{C}$. Blood was also collected and the serum was separated for to determine the level of marker enzymes $\gamma$-glutamyltranspeptidase (GGT) (Orlowski et al., 1965) and lactate dehydrogenase (LDH) (King, 1965). Analysis of Complete Blood count was performed and whole blood was collected into an EDTA contained sterile specimen tube (BD Vacutainer; Beckton, Dickinson and Company USA) for haematological analysis. The whole blood sample was determined for the changes in the blood cells automated analyser: ACT Diff Analyzer (Beckman Coulter USA),

\section{Histopathological Analysis of Lungs}

The lung tissues were collected and processed for histopathological analysis as per standard protocol. The lung specimens were collected from each group of animals and were fixed in $10 \%$ formalin, dehydrated, embedded in paraffin and cut into $4 \mu \mathrm{m}$ sections. The paraffin sections were deparafinized with xylene, hydrated and stained with hematoxylin and eosin. The stained sections of lungs tissue samples were examined for histopathological analysis. A certified histopathologist performed all analysis using an EVOS-xl CORE light microscope (AMG, Bothell, WA).

\section{Immunohistochemical Analysis}

Lung tissue were collected from each group, fixed in 4\% neutral formalin, dehydrated with increasing concentrations of ethanol, embedded in paraffin, and sectioned. The 5- $\mu \mathrm{m}$ thick 
sections were processed and immunohistochemical analysis of p53 and Bcl-2 were performed using primary antibody against $\mathrm{p} 53$ or $\mathrm{Bcl}-2$ [polyclonal murine anti-p53 or $\mathrm{Bcl}-2$ antibody; dilution = 1:400 in PBS, (Abcam, Cambridge, MA, USA)]. Finally, the sections were stained with hematoxylin, mounted with glycerin and examined under a light microscope at 100X magnification.

\section{STATISTICAL ANALYSIS}

Statistical data analysis were expressed as mean $\pm \mathrm{SD}$, the results were computed statistically using one-way anova p-Values: $\mathrm{p}<0.05$ were considered to be statistically significant.

\section{RESULTS AND DISCUSSION}

\section{Biochemical Analysis}

The animals were sacrificed on the Day 61 after induction of cancer. Blood was collected and serum was separated and used for the estimation of LDH and GGT activity. The effect of Artocarpus heterophyllus on serum biochemical Lactate dehydrogenase (LDH) and $\gamma$-glutamyl transpeptidase (GGT) and blood parameters include haemoglobin and WBC in control and experimental group of mice are showed in Table 1. The Haemoglobin level was highly increased in the extract treated groups $(12.80 \pm 3.5 \mathrm{~g} / \mathrm{dL})$ when compared with the benzopyrene induced control. Similarly, the WBC Count also showed elevated level in the extract treated group when compared to the normal.

Serum LDH and GGT the marker enzymes also showed an elevated level in control groups $(1029.93 \pm 8.18 \mathrm{U} / \mathrm{L}$ and $13.55 \pm 0.42 \mathrm{U} / \mathrm{L})$. After the treatment with Artocarpus heterophyllus spermoderm extract enzyme activities were retained to near normal range in extract treated Group III and in Group IV $(728.6 \pm 8.18 \mathrm{U} / \mathrm{L}, 3.81 \pm 0.15 \mathrm{U} / \mathrm{L}$ and $610.6 \pm 9.97$ 
$\mathrm{U} / \mathrm{L}, 4.37 \pm 0.15 \mathrm{U} / \mathrm{L})$. Table 2 shows the level of serum marker enzymes in control and experimental group.

Table 1. Effect of benzopyrene on Artocarpus heterophyllus hydroethanolic extract on Haematological profile

\begin{tabular}{|c|c|c|c|c|}
\hline Blood indices & Normal & $\begin{array}{c}\text { B(a)P Induced } \\
\text { Control }\end{array}$ & $\begin{array}{c}\text { B(a)P+ Extract } \\
\mathbf{( 5 0 m g / k g / b . w t )}\end{array}$ & $\begin{array}{c}\text { B(a)P+ Extract } \\
\mathbf{( 1 0 0 m g / k g / b . w t )}\end{array}$ \\
\hline $\mathrm{Hb}(\mathrm{g} / \mathrm{dL})$ & $11.70 \pm 1.1$ & $10.33 \pm 3.6 \mathrm{a}^{*}$ & $12.73 \pm 3.0 \mathrm{~b}^{*}$ & $12.80 \pm 3.5 \mathrm{c}^{*}$ \\
\hline $\begin{array}{c}\mathrm{WBC}\left(\times 10^{\wedge} 3\right. \\
\mathrm{cells} / \mu \mathrm{L})\end{array}$ & $11.60 \pm 0.7$ & $14.43 \pm 4.5 \mathrm{a}^{*}$ & $13.17 \pm 3.4 \mathrm{~b}^{*}$ & $10.63 \pm 3.4 \mathrm{c}^{*}$ \\
\hline
\end{tabular}

Values are expressed as the mean \pm standard deviation in each group $* \mathrm{P}<0.05$ as compared to the Normal

Table 2. Effect of benzopyrene and hydroethanolic extract on serum marker enzymes in control and experimental group

\begin{tabular}{|c|c|c|c|c|}
\hline Parameters & $\begin{array}{c}\text { Group I } \\
\text { (Normal) }\end{array}$ & $\begin{array}{c}\text { Group II } \\
\text { (B(a)P Induced) } \\
\text { Control }\end{array}$ & $\begin{array}{c}\text { Group III } \\
\text { B(a)P+ Extract } \\
(\mathbf{5 0 m g} / \mathbf{k g} / \mathbf{b . w t})\end{array}$ & $\begin{array}{c}\text { Group IV } \\
\text { B(a)P+ Extract } \\
(\mathbf{1 0 0 m g} / \mathbf{k g} / \mathbf{b} . w t)\end{array}$ \\
\hline LDH (U/L) & $540.87 \pm 2.06$ & $1029.93 \pm 8.18 \mathrm{a}^{*}$ & $728.6 \pm 8.18 \mathrm{~b}^{*}$ & $610.6 \pm 9.97 \mathrm{c}^{*}$ \\
\hline GGT (U/L) & $3.82 \pm 0.17$ & $13.55 \pm 0.42 \mathrm{a}^{*}$ & $3.81 \pm 0.15 \mathrm{~b}^{*}$ & $4.37 \pm 0.15 \mathrm{c}^{*}$ \\
\hline
\end{tabular}

Values are expressed as the mean \pm standard deviation in each group $* \mathrm{P}<0.05$ as compared to the Normal 


\section{Effect of Artocarpus heterophyllus on Histopathological analysis of lung tissue}

The histological examination of the lung section of control and experimental group was depleted in Plate 1. The lung tissues sections were stained with Hematoxylin and eosin. Normal structure and small identical nuclei revealed in control animal Group I. Benzopyrene induced lung cancer bearing Group II showed abnormality in their structure with distorted alveoli as evidenced from increased number of hyperchromatic nuclei in the cells of alveolar wall. Group III exhibited normal architecture indicating the non-toxic nature of Artocarpus heterophyllus. In Group IV with Artocarpus heterophyllus showed markedly reduced alveolar damage in animals thereby preserving the near normal architecture.
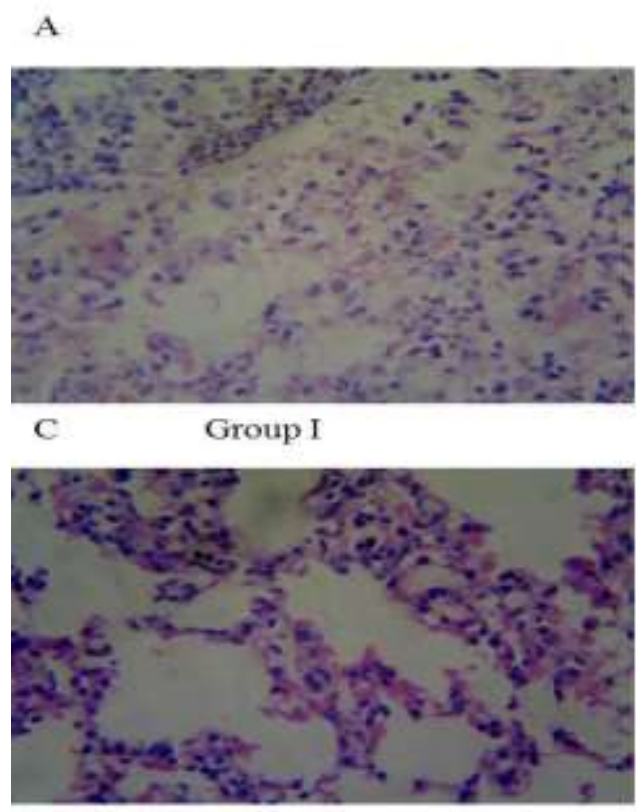

Group III

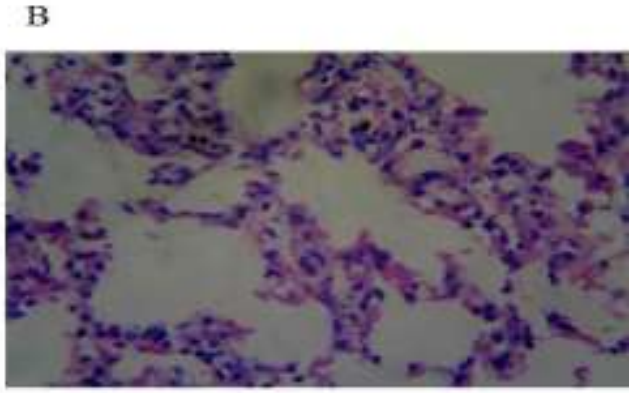

Group II

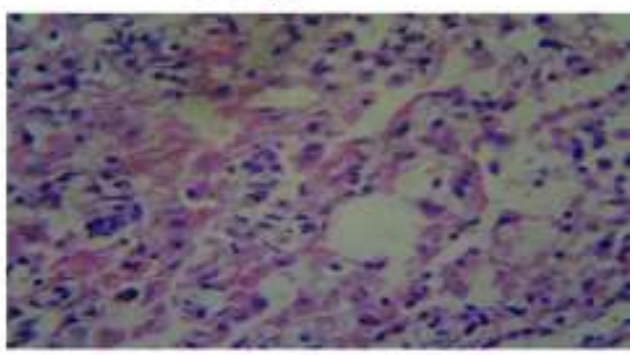

Group IV
A- Normal
B- B(a)P Induced Control
C- B(a)P + Extract $(50 \mathrm{mg} / \mathrm{kg} / \mathrm{b} . \mathrm{wt})$
D- B(a)P + Extract (100mg/kg/b.wt)

Plate 1. Histopathological Examination of Lung sections

Group I -Normal 40x shows inflammatory infilterates composed of lymphocytes and neutrophils, Group II shows 40x shows neoplasm with lymphocytic infiltrates, Group III drug 
40x shows inflammatory infiltrates, Group IV drug 40x shows congestion with inflammatory infilterates.

\section{Effect of Artocarpus heterophyllus on Immunohistochemical localization of p53 and Bcl-2}

The immunohistochemical (IHC) analysis reveals the expression of p53 tumor suppressor gene and Bcl-2 oncoprotein (anti-apoptotic protein) between control and experimental group treated with extracts of Artocarpus heterophyllus in different concentration. The results showed that there was increased number of p53 immunoreactive cells in the lung tissue of mice in two different concentration treated with Artocarpus heterophyllus when compared to the control group. In contrast, there were significant increased numbers of Bcl-2 immunoreactive cells in the lung tissues of control group. Mice treated with Artocarpus heterophyllus in two different concentrations reduced the overexpression of Bcl-2 immunoreactive cells (Plate $2 \& 3$ ).
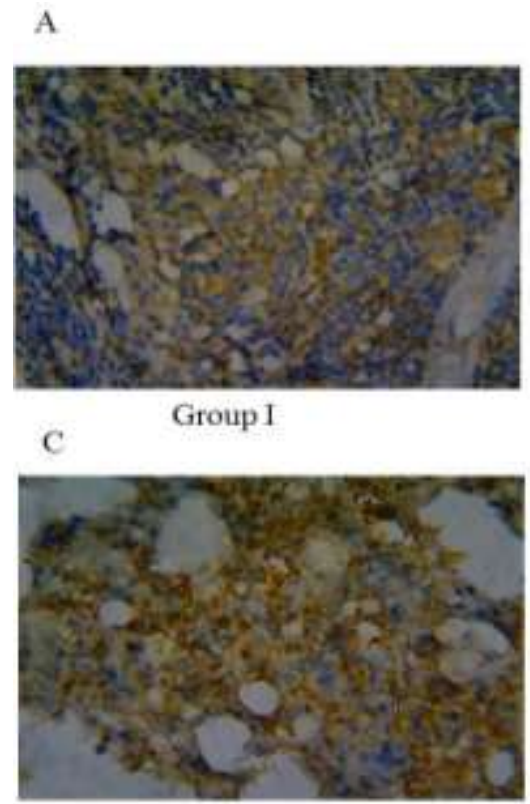

Group III

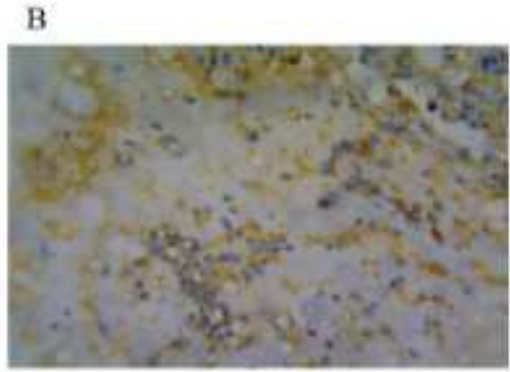

Group II

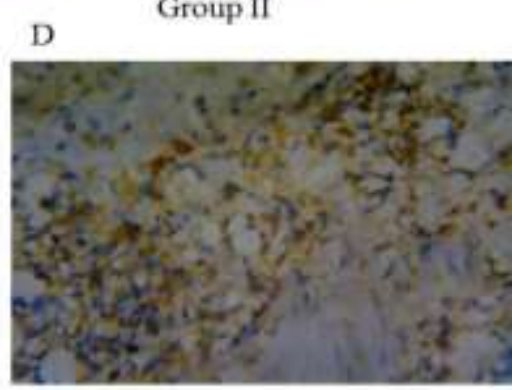

Group IV

A- Normal

B- B(a)P Induced Control

C- B(a)P+ Extract (50mg/kg/b.wt)

D- B(a)P + Extract $(100 \mathrm{mg} / \mathrm{kg} / \mathrm{b}$.wt $)$

Plate 2. Immunohistochemical localization of p53 tumor suppressor gene 

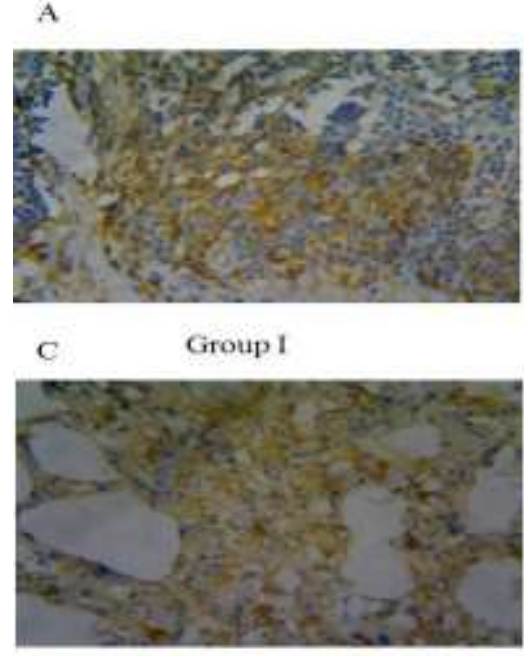

Group III
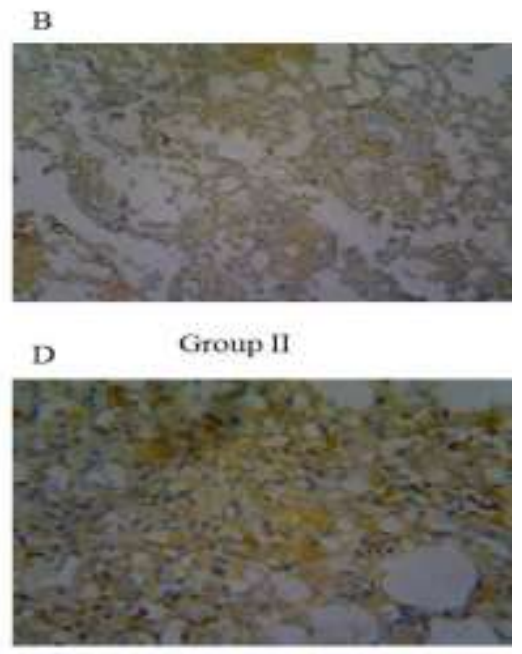

Group IV
A- Normal
B- B(a)P Induced Control
C- B(a)P+ Extract $(50 \mathrm{mg} / \mathrm{kg} / \mathrm{b}, \mathbf{w t})$
D. B(a)P+ Extract (100mg/kg/b.wt)

Plate 3. Immunohistochemical localization of $\mathrm{Bcl} 2$ tumor suppressor gene

Benzopyrene a well-known carcinogen promotes oxidative stress and plays a significant role in lung carcinogenesis. The benzopyrene induced lung cancer in mice offers a significant model to study the effect of natural products and has been extensively used by many researchers and found extensive success in ameliorating the pathophysiological changes of lung cancer (Zuo et al., 2014). B(a)P causes DNA adduct formation, which is the initiating event in carcinogenesis (Wang et al., 2015). B(a)P has also been demonstrated to promote A549 cell migration and invasion by releasing various tumour markers (Wenjie et al., 2014). In our present study, serum markers showed significant decrease in Artocarpus heterophyllus treated group when compared to the benzopyrene induced group. A serum tumour marker has extended extensive application in early diagnosis, treatment effect monitoring and prognosis evaluation. Serum tumour markers possess the advantages of recognition, noninvasive operation, and cost-effectiveness (Corti et al., 2010). 
Gamma-glutamyl transferase (GGT) is a vital enzyme involved in glutathione metabolism and whose expression is often considerably increased in human malignancies. Several studies concentrated on the possible role of GGT in tumour progression, invasion and drug resistance. The association of a pro-oxidant activity of GGT, besides its early recognized contributions to cellular antioxidant defenses, has been repeatedly documented (Zhang et al., 2015). LDH is also a potential predictive marker to escort individual therapy decisions in solid tumours (Xie et al., 2014). Inhibiting LDH expression may reduce invasiveness and the metastatic potential of cancer cells by reducing their proliferation capacity and retreating their resistance to chemotherapy, LDH can consequently be regarded as an epitome target for anticancer therapies (Zhang et al., 2015). Apoptotic markers-cell-lymphoma-2 (Bcl-2) is a proto-oncogene that plays an important role in the regulation of apoptosis and cell survival (Zhang et al., 2015). The functional association of p53 with the downstream regulated proteins Bcl-2, the interrelationship between the markers was assessed. Our study revealed the correlation between p53 and Bcl-2 in lung cancer tissue.

\section{CONCLUSION}

The data from the present study highlights the anticancer activity of spermoderm extract of Artocarpus heterophyllus could be useful in search for anticancer agent. The results obtained in the haematological analysis and marker enzymes showed a marked decrease associated with benzopyrene treated group. The histopathological and immunohistochemical analysis also revealed the inhibition of lung cancer progression by regulating p53 and Bcl-2 proteins. However, further studies are necessary to elucidate the molecular mechanisms involved in anticancer activity. Artocarpus heterophyllus might be used as a promising candidate for the drug development of anticancer therapeutics. 


\section{ACKNOWLEDGMENT}

We like to thank the Dr. C. Guruvayoorappan and Dr. K. M. Sakthivel, Karunya University, for support through the provision of laboratory facilities and general equipment for the research.

\section{CONFLICT OF INTEREST}

There is no conflict of interest in the present study.

\section{REFERENCES}

1. Adebayor H, (2010). Anticancer and antiradical scavenging activity of ageratum conzoides L.(asteraceae), Phcog Mag ;6(21):62-6.

2. Ali J, et.al, (2017).Protocol optimization for in vitro shoot multiplication of Jackfruit [Artocapus heterophyllusL.]. Arf J Biotechnol ;169(20):87-90.

3. Apte K G, (2016).Medicinal plants as potential source of anticancer agents, $\mathrm{J}$ pharmacog and phytochem;5(2):291-95.

4. Corti, A., Franzini, M., Paolicchi, A., and Pompella, A. (2010). Gammaglutamyltransferase of Cancer Cells at the Crossroads of Tumor Progression. Drug Resistance and Drug Targeting, Anticancer Research, 30:1169-82.

5. Fuadhafid A, (2017). Antiviral activity of the dichloromethane extracts from Artocarpus heterophyllus leaves against hepatitis C virus. Asian Pacific Jour of Tropical Biomedicine;7(7):633-9.

6. Greenwell M and Rahman P K, (2015). Medicinal Plants: Their Use in Anticancer Treatment, Int J Pharm Sci Res;6(10):4103-12.

7. King, C. (1965). The transferases-alanine and aspartate transaminases. In: Van D (ed.). Practical Clinical Enzymology. Nostrand Company Ltd., London;121-38.

8. Nath R, et al, (2017). Growth performance of goats as affected by supplementation of medicinal leaves. International Journal of Chemical Studies;5(1):151-3.

9. Ngamkitidechakul C, Jaijoy K, Hansakul P, Soonthornchareonnon N, Sireeratawong S, (2010).Antitumor effects of Phyllanthusembilca L.Induction of cancer cell apoptosis and in vivo tumour promotion and in vivo invasion of human cancer cells. Phytotherapy res;24:1405-13.

10. Obeidat M and Sharab S, (2018).Antimicrobial and anticancer activities of extract from Urginea marithma fruits, J Tradit Complement alter med. 2018;15(1):74-84. 
11. Orlowski, $M$ and Meister, A (1965). Isolation of $\gamma$-Glutamyl Transpeptidase from Hog Kidney. J Biol Chem; 240 :338-47.

12. Prakash O, Amit Kumar A, Kumar P and Ajeet, (2013). Anticancer potential of plants and natural products; A review, Ameri J pharma Sci;6: 104-15.

13. Rajandeepkaur, (2011). Anticancer plant .journal of natural product, Plant resource; $1(4): 1316$.

14. Rethy B, (2007).Antitumor effect of plants extracts and their constituents on cancer cell lines; 72:767-70.

15. Sudhakar S (2009). History of cancer ancient and modern treatment methods, Jour canc Sci;1(2):1-4.

16. TiwariA,A(2017). Review on traditional plants and herbs are used to evaluation for their ant icancer potential. Jour of Pharm Res;11(5):547-53.

17. Vanitha V, Hemalatha S, Pushpabharathi N, Amudha P, M. Jayalakshmi M (2017). Fabrication of nanoparticles using Annonasquamosa leaf and assessment of its effect on liver (HepG2) cancer cell lines. International Conference on Mining, Material and Metallurgical Engineering; 191(1):012010.

18. Wang, Y., Zhai, W., Wang, H., Xia, X and Zhang, C (2015).. Benzopyrene promotes A549 cell migration and invasion through up-regulating Twist. Arch Toxicol; 89:451-58.

19. Wenjie, Q., Xuechang, Li., and Kang, J (2014).. Advances in the study of serum tumor markers of lung cancer. J Can Res Ther;10:95-101.

20. Xie, H., Hanai, J., Ren, J.G., Kats, L., Burgess, K. and Bhargava, P (2014).Targeting lactate dehydrogenase-inhibits tumorigenesis and tumor progression in mouse models of lung cancer and impacts tumor-initiating cells. Cell Meta. 19:795-809.

21. Zhang, J., Wang S, Wang, L., Wang, R., Chen, S., Pan, B., Sun, Y., and Chen, H (2015).. Prognostic value of Bcl-2 expression in patients with non-small-cell lung cancer: a metaanalysis and systemic review, Onco Targets Ther. 8:3361-69.

22. Zhang, J., Yao, Y., Li, B., Yang, Q., Zhang, P and Wang, H (2015).. Prognostic value of pretreatment serum lactate dehydrogenase level in patients with solid tumors: a systematic review and meta-analysis, Scientific Reports; 5:9800. 
23. Zuo, J., Brewer, DS., Arlt, VM., Cooper, CS and Phillips, DH (2014). Benzopyreneinduced DNA adducts and gene expression profiles in target and non-target organs for carcinogenesis in mice. BMC Genomics; 15:880. 